\title{
Groundwater studies in tropical islands: Malaysian perspective
}

\author{
${ }^{1}$ School of Science and Technology, Universiti Malaysia Sabah, Locked Bag 207388999 Kota Kinabalu, Sabah, Malaysia. \\ E-mail: smpraveena@gmail.com \\ ${ }^{2}$ Faculty of Environmental Studies, Universiti Putra Malaysia, 43400 UPM Serdang, Selangor, Malaysia \\ ${ }^{3}$ Water Research Unit, School of Science and Technology, Universiti Malaysia Sabah, 88999 Kota Kinabalu, Sabah, Malaysia
}

Groundwater studies related to tropical islands in Malaysia are briefly reviewed. Perspectives are addressed as three aspects: (a) study location, where groundwater studies in Malaysia are conducted in different types of tropical islands (b) methods, namely numerical modeling, geophysical investigations, hydrochemical analysis and geochemical modeling were applied in the studies of groundwater where numerical modeling is the most used method in groundwater studies of Malaysian coastal environment and tropical islands; (c) types of studies, where most of groundwater studies are more focused in investigating the groundwater resources and management as well as seawater intrusion using numerical models and geophysical investigations. This review revealed that main objectives in most of Malaysian groundwater studies in tropical islands are groundwater resources, management as well as mechanism and processes of seawater intrusion phenomenon. This showed that groundwater studies in Malaysia focusing in tropical islands are clearly needed to be increased and strategized in terms of research objectives. Based on previous studies, future studies should give a focus in other types of investigations in utilization of this resource in order to fill in the knowledge gap of groundwater to provide clear direction in sustainable development of this precious resource.

\section{Introduction}

Tropical islands in Malaysia are endowed with magnificent beaches, clear waters and extensive reef formation. This promotes Malaysia as an outstanding tourist destination and has brought lot of benefits in terms of economic growth. Although tourism is an important economic driver in coastal environment and tropical islands, uncontrolled tourism development, however, will degrade the coastal development. Destruction of the ecosystem near shore and depletion of its groundwater resources are few of them. On many tropical islands, surface water is absent and groundwater is a vital source of freshwater for daily domestic consumption and tourism activities. Moreover, the groundwater is also an important source of drinking water in these islands (White et al., 2007).

On such islands, aquifers are highly permeable and soils are usually thin, aquifers are highly vulnerable and water can only be tapped at shallow depths. Thin lenses of fresh groundwater floating over seawater are very much vulnerable to various threats (Dillon, 1997). Threats received by groundwater of Malaysian small islands are from natural and human pressures. Natural pressures are climate change, sea level rise and variations in tropical and extra-tropical cyclones, hurricanes as well as typhoons. Such natural challenges can affect both quantity and quality of groundwater in small islands. Pressures associated with human settlement in groundwater of tropical islands are such as human pressures (overpumping) and seawater intrusion problem, tourism competition pressures with other islands and others. Human pressure by overpumping is the main critical factor in Malaysian small islands. In order to meet the water demand, overpumping resulted in seawater intrusion in groundwater of Malaysian small islands (Praveena and Aris, 2009a). All these challenges and effects will be faced by the local population, tourism industry and economy profits (Gössling, 2001).

This paper attempts to guide some of the important sources of information on groundwater studies of tropical islands that have been published in Malaysia. A number of groundwater studies have been conducted for tropical islands, however, they are not extensively reviewed. An overall viewpoint of Malaysian groundwater studies is needed for tropical islands to give a clear picture and direction. Thus, this paper is an attempt to review the groundwater studies conducted in tropical islands in Malaysia. The review discusses the groundwater studies in Malaysia focusing perspectives of study locations, methods and types of studies. The output of this review will be able to provide a direction for future studies involving Malaysian tropical islands.

\section{Materials and Methods}

\section{Hydro-meteorological characteristics}

The climate in Malaysian tropical islands is hot and humid throughout the year. The temperature rarely drops below $20^{\circ} \mathrm{C}$ even at night, and usually reaches $30^{\circ} \mathrm{C}$ or more during the day. Humidity 
is generally about $90 \%$. The rainfall is the highest during Monsoon season, high is between December and early February. However, East Malaysia (Sabah and Sarawak) have a more maritime climate (ocean influenced) compared to West Malaysia.

\section{Hydrogeological characteristics}

Much of Malaysia is formed from sedimentary rocks that were created by accumulation and compaction of loose sediments. Limestone is one of the main Paleozoic sedimentary rocks which is found in thick layers. Heavy erosion of easily eroded limestone is found in Sabah and Sarawak. Sandy beaches are found primarily on Malaysian tropical islands. The soil cover is generally thin and not agriculturally productive (Marshall Cavendish Corporation, 2007). Few of hydro-geological characteristics of Malaysian tropical islands with examples such as in Langkawi, Manukan, Sipadan and Tioman, Gunung Matchincang in Langkawi Island was the first part of SouthEast Asia to rise from the seabed during the Cambrian period. The oldest part of the formation consists of mainly sandstone (quartzite) in the upper parts and shale and mudstone in the lower parts of the sequence (Junaidah and Jamal, 1996). Tioman Island is a volcanic island which predominantly features rocky hills (Abdul Rahim, 2002). Manukan Island is underlain by folded sandstone and other sedimentary rocks are part of the Crocker Range Rock Formation of the western coast of Sabah (Abdullah, 2001). Sipadan Island is composed of several series of Quaternary bioherm facies, which has high porosity and permeability properties (Abdullah et al., 2010).

\section{Perspectives of groundwater studies conducted in Malaysian tropical islands}

Existing groundwater studies in Malaysian tropical islands were analyzed and reviewed in the perspectives of methods, study locations and types of studies (Fig.1). Generally, groundwater studies in Malaysian tropical islands have been limited to academic and research purposes.

\section{Study Location Perspective}

West Malaysia has focused on large islands compared to small tropical islands in East Malaysia. Large tropical islands communities in Malaysia rely on groundwater for their water supply besides piped water supply. Small tropical islands, mostly in East Malaysia, have limited alternatives to develop their freshwater resources. Surface water does not exist in exploitable form; fresh groundwater is the sole option to meet the water demand. The freshwater lens on tropical islands may easily be overexploited or polluted due to dense development combined with improper management, vulnerable to climate change and the associated impacts on freshwater resources. Overdrafts of freshwater by pumping wells distort the natural rechargedischarge equilibrium causing declining of the water table or upconing of the saltwater interface. Thus, groundwater studies in small tropical islands are crucial to protect the freshwater resources and require careful investigation and management.

\section{Methods Perspective}

Numerical modeling is the most used method in groundwater studies of Malaysian coastal environment and tropical islands. This is most probably influenced by advantages of numerical models application in groundwater studies. Although other methods (geophysical investigations, hydrochemical analysis and geochemical modeling) have their own advantages in groundwater studies, computer technology has resulted in groundbreaking of various numerical models to dominate the complex and dynamic groundwater in small islands (Simmons et al., 2001). Groundwater studies in Malaysia using numerical models was done using ASMWIN-Aquifer Simulation Model for Windows, Visual MODFLOW and MT3D model, SUTRA and SEAWAT-2000 (Table 1). Most of the numerical models were used to investigate the groundwater flow and transport of contaminants, such as nitrate, in the groundwater studies in Malaysia. It is because septic tanks are the potential source of nitrate contamination in groundwater, due to effluent discharge through the seepage pits (Rahman and Kuan, 2004). Studies by Rahman and Kuan (2004) in Tioman Island using Visual MODLFOW and Kuan (2003)

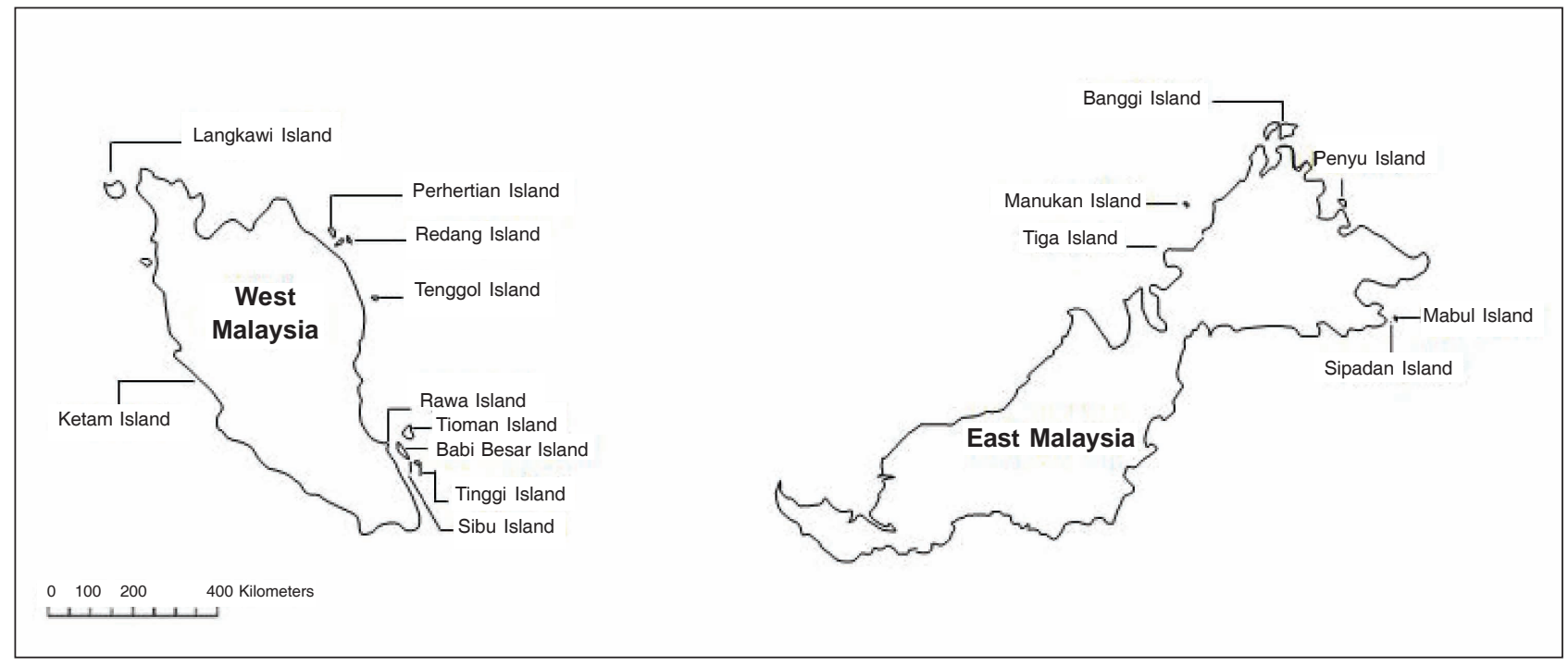

Figure 1. Malaysian states with famous tropical islands (Source: modified from Aris et al., 2008) 
Table 1. Groundwater modeling studies in Malaysia by means of numerical modeling

\begin{tabular}{|l|l|l|l|}
\hline \multicolumn{1}{|c|}{ Reference } & \multicolumn{1}{|c|}{ Island } & \multicolumn{1}{|c|}{ Method } & \multicolumn{1}{c|}{ Objective } \\
\hline $\begin{array}{l}\text { Abdullah } \\
\text { (2001) }\end{array}$ & Manukan & SUTRA & $\begin{array}{l}\text { To assess the extent of } \\
\text { seawater intrusion }\end{array}$ \\
\hline $\begin{array}{l}\text { Daulay et al. } \\
\text { (2001) }\end{array}$ & Tioman & $\begin{array}{l}\text { Aquifer } \\
\text { Simulation } \\
\text { Model (ASM) }\end{array}$ & $\begin{array}{l}\text { To investigate the quantity } \\
\text { of water resource by } \\
\text { looking at groundwater } \\
\text { extraction }\end{array}$ \\
\hline $\begin{array}{l}\text { Praveena et al. } \\
\text { (2009b) }\end{array}$ & Manukan & $\begin{array}{l}\text { SEAWAT- } \\
\text { 2000 }\end{array}$ & $\begin{array}{l}\text { To assess the extent of } \\
\text { seawater intrusion }\end{array}$ \\
\hline $\begin{array}{l}\text { Abdul Rahim } \\
\text { (2002) }\end{array}$ & Tioman & $\begin{array}{l}\text { Visual } \\
\text { MODFLOW }\end{array}$ & $\begin{array}{l}\text { To assess the flow and } \\
\text { transport of contaminant } \\
\text { (nitrate) }\end{array}$ \\
\hline $\begin{array}{l}\text { Rahman and } \\
\text { Kuan (2004) }\end{array}$ & Tioman & $\begin{array}{l}\text { Visual } \\
\text { MODLFOW }\end{array}$ & $\begin{array}{l}\text { To assess the flow and } \\
\text { transport of contaminant } \\
\text { (nitrate) due to withdrawal }\end{array}$ \\
\hline $\begin{array}{l}\text { Abdullah et al. } \\
\text { (2010) }\end{array}$ & Sipadan & $\begin{array}{l}\text { SEAWAT- } \\
\text { 2000 }\end{array}$ & $\begin{array}{l}\text { To assess the extent of } \\
\text { seawater intrusion }\end{array}$ \\
\hline $\begin{array}{l}\text { Praveena et al. } \\
\text { (2010a) }\end{array}$ & Manukan & $\begin{array}{l}\text { SEAWAT- } \\
\text { 2000 }\end{array}$ & $\begin{array}{l}\text { To assess the effect of } \\
\text { recharge rate on ground- } \\
\text { water resource }\end{array}$ \\
\hline $\begin{array}{l}\text { Praveena et al. } \\
\text { (2010b) }\end{array}$ & Manukan & $\begin{array}{l}\text { SEAWAT- } \\
\text { 2000t }\end{array}$ & $\begin{array}{l}\text { To quantify he water } \\
\text { balance components }\end{array}$ \\
\hline
\end{tabular}

in Kota Bharu using Visual MODFLOW and MT3D model have showed that numerical models are suitable to demonstrate the transport of contaminants and compliance with regulations. Numerical modeling is also used to determine the suitable pumping and recharge rates in groundwater. Such studies were more focused in tropical islands in East Malaysia, in Manukan Island, to protect the groundwater resources (Praveena et al., 2010a). Thus, numerical models have become a tool in groundwater investigation to determine the appropriate pumping rates suitable in tropical islands.

Hydrochemical analysis is the second most used method in groundwater studies for Malaysian tropical islands (Table 2). It has been used widely in East Malaysia's tropical islands namely Manukan, Sipadan, Mabul and Tiga. This is due to being an easy and rapid way

Table 2. Groundwater modeling studies in Malaysia based on hydrochemical analysis

\begin{tabular}{|l|l|l|}
\hline Reference & \multicolumn{1}{|c|}{ Island } & \multicolumn{1}{c|}{ Objective } \\
\hline $\begin{array}{l}\text { Abdullah and } \\
\text { Musta (1999) }\end{array}$ & Selingaan & $\begin{array}{l}\text { To determine the groundwater } \\
\text { characteristics }\end{array}$ \\
\hline $\begin{array}{l}\text { Abdullah and } \\
\text { Musta (1999) }\end{array}$ & Bakkungan Kechil & $\begin{array}{l}\text { To determine the groundwater } \\
\text { characteristics }\end{array}$ \\
\hline Aris et al. (2006) & Mabul & $\begin{array}{l}\text { To characterize the hydrogeo- } \\
\text { chemistry facies and indicate } \\
\text { seawater intrusion }\end{array}$ \\
\hline $\begin{array}{l}\text { Aris et al. (2008, } \\
\text { 2009) }\end{array}$ & Manukan & $\begin{array}{l}\text { To assess the extent of sea- } \\
\text { water intrusion using } \\
\text { geochemical properties }\end{array}$ \\
\hline $\begin{array}{l}\text { Abdullah et al. } \\
\text { (2008) }\end{array}$ & Sipadan & $\begin{array}{l}\text { To characterize the hydrogeo- } \\
\text { chemistry characteristics }\end{array}$ \\
\hline Yik et al. (2009) & Tiga & $\begin{array}{l}\text { To characterize the hydrogeo- } \\
\text { chemistry facies }\end{array}$ \\
\hline
\end{tabular}

to determine the groundwater quality and types. The $\mathrm{Na}-\mathrm{Cl}$ water type illustrates the impact of seawater intrusion in these islands. In areas with seawater intrusion, the problem is high concentration of $\mathrm{Cl}^{-}$which acts as a major pollutant. Human impacts, such as overextraction, are the main causes of seawater intrusion in tropical islands. Water quality analysis is one of the most important aspects in groundwater studies. The hydrochemical analysis output can be utilized to understand the changes in groundwater quality due to rockwater interaction or any type of anthropogenic influence. Groundwater often consists of seven major chemical elements $\mathrm{Ca}^{2+}, \mathrm{Mg}^{2+}, \mathrm{Cl}^{-}$, $\mathrm{HCO}_{3}^{-}, \mathrm{Na}^{+}, \mathrm{K}^{+}$, and $\mathrm{SO}_{4}^{2-}$. The chemical parameters of groundwater play a significant role in classifying and assessing groundwater quality. Moreover, presentation of chemical analysis in graphical form makes understanding of complex groundwater system simpler and quicker. Hydrochemical analysis contains the output of chemical parameters which can be compared with water guidelines and regulations. Such approach has been used by Aris et al. (2009) in Manukan Island, Abdullah et al. (2008) in Sipadan Island and Yik et al. (2009) in Tiga Island.

According to Daniels et al. (1995), geophysical investigations are important in defining the subsurface geology and the associated parameters which govern the movement of contaminant plumes. Most of groundwater studies in Malaysia using geophysical investigations have employed geoelectrical techniques in tropical islands to map the groundwater characteristics using salinity ranges or to determine freshwater/seawater interface (Table 3). Transient electromagnetic method was originally designed for mineral investigation. However, it became popular for hydrogeological investigation in a very limited way over the last two decades (Kirsch, 2006). In Malaysia, transient electromagnetic method has been applied in Tioman and Langkawi islands to determine the potential location for groundwater resource development. According to Abdul Rahim and Abdul Ghani (2002), the selection of technique in geophysical method depends on the size of the site and amount of data required. In a nutshell, the geophysical investigations provide a rapid cost effective way for hydrogeological investigations and found to be suitable in island groundwater studies due to their easy measurement phase and economically viable. Although, much information may be derived from a simple assessment of the survey data, many of the other geophysical methods require complex methodology and relatively advanced mathematical treatment in interpretation which limit their applications for groundwater studies in tropical islands.

Groundwater studies by means of geochemical modeling are new approach in Malaysia (Table 4). So far, only PHREEQC model has

Table 3. Groundwater modeling studies in Malaysia using geophysical investigation

\begin{tabular}{|l|l|l|l|}
\hline \multicolumn{1}{|c|}{ Reference } & \multicolumn{1}{c|}{ Island } & \multicolumn{1}{c|}{ Method } & \multicolumn{1}{c|}{ Objective } \\
\hline $\begin{array}{l}\text { Junaidah and } \\
\text { Jamal (1996) }\end{array}$ & Langkawi & $\begin{array}{l}\text { Transient } \\
\text { Electromagnetic } \\
\text { Method }\end{array}$ & $\begin{array}{l}\text { To report the potential area } \\
\text { for groundwater resource } \\
\text { development }\end{array}$ \\
\hline $\begin{array}{l}\text { Ismail and } \\
\text { Mohd Rais } \\
\text { (2000) }\end{array}$ & Tioman & $\begin{array}{l}\text { Transient } \\
\text { Electromagnetic } \\
\text { Method }\end{array}$ & $\begin{array}{l}\text { To determine the potential } \\
\text { location for groundwater } \\
\text { resource development }\end{array}$ \\
\hline $\begin{array}{l}\text { Abdullah } \\
\text { (2001) }\end{array}$ & Manukan & Seismic & $\begin{array}{l}\text { To determine hydrogeo- } \\
\text { logical characteristics }\end{array}$ \\
\hline $\begin{array}{l}\text { LESTARI } \\
\text { (2005) }\end{array}$ & Sipadan & Seismic & $\begin{array}{l}\text { To determine hydrogeo- } \\
\text { logical characteristics }\end{array}$ \\
\hline
\end{tabular}


Table 4. Groundwater modeling studies in Malaysia using geochemical modeling

\begin{tabular}{|l|l|c|l|}
\hline Reference & Location & Method & \multicolumn{1}{c|}{ Objective } \\
\hline $\begin{array}{l}\text { Aris et al. } \\
(2009)\end{array}$ & $\begin{array}{l}\text { Manukan } \\
\text { Island }\end{array}$ & PHREEQC & $\begin{array}{l}\text { To assess the extent of sea- } \\
\text { water intrusion using } \\
\text { geochemical method }\end{array}$ \\
\hline $\begin{array}{l}\text { Abdullah et al. } \\
(2008)\end{array}$ & $\begin{array}{l}\text { Sipadan } \\
\text { Island }\end{array}$ & PHREEQC & $\begin{array}{l}\text { To assess the extent of sea- } \\
\text { water intrusion using } \\
\text { geochemical method }\end{array}$ \\
\hline
\end{tabular}

been applied in groundwater samples of Manukan and Sipadan islands to demonstrate the extent of seawater intrusion geochemically in Malaysia (Aris et al., 2009). The geochemical model output of PHREEQC showed the saturation indices for selected minerals and ionic concentration changes in groundwater (Aris et al., 2008; 2009; Abdullah et al., 2008). PHREEQC is a computer program designed to perform a wide variety of low-temperature aqueous geochemical calculations. Advantages of using PHREEQC over other geochemical models are that it is capable of handling higher ionic strengths, versatile and suitable to use in density dependent environment (seawater intrusion) which could not be found in other geochemical models. PHREEQC model is able to provide an understanding of hydrochemical processes that take place in the aquifer during the freshwater-seawater mixing (Aris et al., 2009).

\section{Types of Studies Perspective}

Groundwater studies in Malaysia have so far been focused on investigating the groundwater resources and seawater intrusion (Tables 1-4). These studies were conducted by means of numerical modeling, geochemical modeling and hydrochemical analysis. Numerical models such as SUTRA and SEAWAT-2000 were used to assess the extent and location of seawater intrusion and upcoming problem. Geochemical model, PHREEQC has been used in tropical islands (Manukan and Sipadan) to understand the geochemical processes taking place during seawater intrusion. Hydrochemical analysis has been widely applied in tropical islands in East Malaysia to demonstrate the seawater intrusion problem via hydro geochemical characteristics. Studies were conducted in the aspects of groundwater quality and characteristic mostly in tropical islands in Malaysia. Groundwater of tropical islands in Malaysia has been mainly used as drinking water. Thus, groundwater quality and characteristic is an important phase to be highlighted in these studies. It can be concluded that groundwater in Malaysian tropical islands has been studied in a limited way as compared to other types of studies perspectives such as submarine discharge, tidal effect, climate change and water balance. Future undertaking groundwater studies in Malaysia should give a focus in other types of studies such as groundwater discharge, tidal effect, artificial recharge and other remedial measures to control seawater intrusion problem for optimal utilization of groundwater resource.

\section{Conclusion}

The review highlights the groundwater studies carried out in Malaysian tropical islands by various methods and approaches.
Perspectives such as types of studies, methods and study locations in groundwater studies were analyzed and discussed. In a nutshell, groundwater studies in Malaysia have been limited to academic and research purposes. Objectives of these studies mainly involved groundwater resources and seawater intrusion phenomenon. This suggests that groundwater studies in Malaysia are still in their infancy and clearly has to go a long way. Provide a direction for future studies involving Malaysian groundwater of tropical islands, further detailed and site-specific information on soils, aquifer sediments and local hydrogeological conditions are clearly needed. Comprehensive groundwater data are to be collected, analyzed and reported in the same mode as surface water and other water-related data as being publicly reported. Key issue is to increase the groundwater studies so that in long-term groundwater research and sustainable performance towards environment can be addressed at the outset. This is crucial step in a way to fill in the knowledge gap of groundwater studies in Malaysia involving tropical islands.

\section{Acknowledgement}

The first author sincerely acknowledges the support by National Science Fellowship (NSF) Scholarship awarded by Ministry of Science, Technology and Innovation (MOSTI), Malaysia for her doctoral study.

\section{References}

Abdul Rahim S. and Abdul Ghani R., 2002, An integrated approach for managing saltwater intrusion in coastal area: Proceeding Regional Symposium on Environment and Natural Resources, Kuala Lumpur, pp.436-444.

Abdul Rahim, W., 2002, Pemodelan Aliran Air Bumi Dan Pengangkutan Bahan Pencemar Akuifer Kampung Tekek, Pulau Tioman: Master Thesis, Universiti Teknologi Malaysia, Malaysia [in Malay].

Abdullah, M.H. and Musta, B., 1999, Phreatic water quality of the turtle islands of East Malaysia: Pulau Selingaan and Pulau Bakkungan Kechil: Borneo Science, v. 6, pp. 1-9.

Abdullah, M.H., 2001, Phreatic water extraction from shallow aquifer of a small island: PhD Thesis, Universiti Teknologi Malaysia, Malaysia [in Malay].

Abdullah, M.H., Mokhtar, M., Musta, B. and Aris, A.Z., 2008, Hydrochemical Analyses of a Disturbed Aquifer of a Small Island in Malaysia: Fresenius Environmental Bulletin, v.17, no. 12a, pp. 1-9.

Abdullah, M.H., Praveena, S.M. and Aris, A.Z., 2010, A Numerical Modeling of Seawater Intrusion into an Oceanic Island's Aquifer - Sipadan Island, Malaysia: Sains Malaysiana, v.39, no. 4, pp. 525-532.

Aris, A. Z., Abdullah, M. H., Kim, K. W. and Praveena, S. M. 2009, Hydrochemical Changes in a Small Tropical Island's Aquifer, Manukan Island, Sabah, Malaysia: Environmental Geology, v. 56, pp. 1721-1732.

Aris, A.Z., Abdullah, M.H. and Musta, B., 2008, Hydrochemical analysis on groundwater in shallow aquifer of Manukan and Mabul islands: Malaysia International Association of Hydrological Science Publication, v.319, pp. 387-394.

Aris, A.Z., Abdullah, M.H. and Woong, K.K., 2006, Hydrochemical Analysis on Seawater Intrusion of Small Carbonate Island; Manukan and Sipadan, Sabah: Proceeding of $2^{\text {nd }}$ Southeast Asian Natural Resources and Environmental Management Conference, Kota Kinabalu, Malaysia.

Daniels, J.J., Roberts, R. and Vendl, M., 1995, Ground penetrating radar for the detection of liquid contaminants: Journal of Applied Geophysics, v. 33, pp. 195-207.

Daulay, H.B., Rahman, N.A., Mohd. Kasim, A. H. and Nasir. K., 2001, Study 
on Water Resources in Tioman Island: Journal Teknologi, v.34, pp. 5162.

Dillon, P., 1997, Groundwater pollution by sanitation on tropical islands: UNESCO International Hydrological Programme V, Technical Documents in Hydrology, no. 6, pp.37.

Gössling, S., 2001, The consequences of tourism for sustainable water use on a tropical island: Zanzibar, Tanzania: Journal of Environmental Management, v.61, pp. 179-191.

Ismail, C.M. and Mohd Rais, R., 2000, Groundwater Potential in Kampung Tekek and Kampung Juara, Pulau Tioman, Pahang: The Regional Conference on Hydrology and Environment of Small Islands, Tioman Island, Malaysia.

Junaidah, A. and Jamal, N., 1996, Boundary of saline groundwater inflow in the region of Sungai Melaka and Sungai Cenang Basin at Langkawi Island: Seminar of Hydrology Research on Small Islands, Langkawi Island, Malaysia [in Malay].

Kirsch, R., 2006, The transient electromagnetic method. Groundwater Geophysics: A Tool for Hydrogeology. Springer, Netherlands.

Kuan, W.K., 2003, Simulation of Groundwater Flow and Pollutant Transport for Alluvial Aquifer in Kg. Tekek and Kg. Juara, Tioman Island: Master Thesis, Universiti Teknologi Malaysia, Malaysia.

Lestari UKM., 2005, Kajian status alam sekitar dan keupayaan tampungan Pulau Sipadan: Universiti Kebangsaan Malaysia, Malaysia [In Malay].

Marshall Cavendish Corporation, 2007. World and Its Peoples: Malaysia, Philippines, Singapore, and Brunei: Marshall Cavendish, Singapore.

Praveena, S.M. and Aris, A.Z., 2009a, A review of groundwater in islands using SWOT analysis: World Review of Science, Technology and Sustainable Development, v. 6, pp. 186-203.

Praveena, S.M., Aris, A. Z. and Abdullah, M.H., 2009b, Modeling of seawater intrusion for a small tropical island aquifer in East Malaysia: Proceedings of International Conference on Chemical, Biological \& Environmental Engineering, Singapore, p202-205.

Praveena, S.M., Abdullah, M.H., Aris, A.Z. and Bidin, K., 2010a, Recharge And Aquifer Response: Manukan Island's Aquifer, Sabah, Malaysia: Environment Asia, v. 3, pp. 72-81.

Praveena, S.M., Abdullah, M.H., Bidin, K. and Aris, A.Z., 2010b, Modeling Of Water Balance Components in Small Island Via A Numerical Model Application: Journal of Coastal Research, (In-Press).

Rahman, N.A. and Kuan, W., 2004, Simulation of groundwater flow and pollutant transport for alluvial aquifer in Kampung Tekek, Tioman Island: Journal Teknologi, v. 41, pp. 21-34.

Simmons, C.T., Voss, C.I., Woods, J.A. and Prasad, A., 2001, Benchmarking variable-density groundwater flow and solute transport models: Approaches, Resolutions and Future Challenges: First International Conference on Saltwater Intrusion and Coastal Aquifers- Monitoring, Modeling, and Management, Essaouira, Morocco.

White, I., Falkland, T., Perez, P., Dray, A., Metutera, T., Metai, E. and Overmars, M., 2007, Challenges in freshwater management in low carol atolls: Journal of Cleaner Production, v.15, pp. 1522-1528.

Yik, L.C., Abdullah, M.H. Aris, A.Z. and Praveena, S.M., 2009, A Baseline Study Groundwater Quality of the Tourist Island, Pulau Tiga, Malaysia: Modern Applied Sciences, v. 3, pp. 62-74.

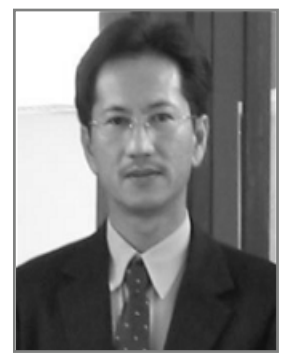

Mohd. Harun Abdullah holds a PhD from Universiti Teknologi Malaysia, MSc from Universiti Kebangsaan Malaysia and BSc from Universiti Putra Malaysia. He specializes in water quality, groundwater pollution assessment in small islands, water resources, hydrochemistry.

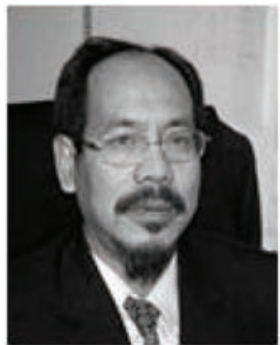

Kawi Bidin holds a $\mathrm{PhD}$ from Lancaster University, MSc from Manchester University and B.Sc from Universiti Kebangsaan Malaysia, Malaysia. Currently, he is Associate Professor in Environmental Science programme and specializes in tropical forest hydrology and water. 